\title{
Trend in infant mortality rate in Argentina within the framework of the Millennium Development Goals
}

\author{
Juliana Z. Finkelstein M.D. ${ }^{a}$, Mariana Duhau M.D. ${ }^{a}$, Ana Speranza M.D. ${ }^{c}$, \\ Lic. Élida Marconi B.S. ${ }^{b}$ and Lic. Paola Escobar B.S. ${ }^{c}$
}

\begin{abstract}
Introduction. Infant mortality rate (IMR) is an indicator of the health status of a population and of the quality of and access to health care services. In 2000, and within the framework of the Millennium Development Goals, Argentina committed to achieve by 2015 a reduction by two thirds of its 1990 infant mortality rate, and to identify and close inter-jurisdictional gaps. The objective of this article is to describe the trend in infant mortality rate in Argentina and interjurisdictional gaps, infant mortality magnitude and causes, in compliance with the Millennium Development Goals.

Population and methods. Adescriptivestudy on infant mortality was conducted in Argentina in 1990 and between 2000 and 2013, based on vital statistics data published by the Health Statistics and Information Department of the Ministry of Health of Argentina.

Results. The following reductions were confirmed: $57.8 \%$ in IMR, $52.6 \%$ in neonatal mortality rate and $63.8 \%$ in post-neonatal mortality rate. The inter-provincial Gini coefficient for IMR decreased by $27 \%$. The population attributable risk decreased by $16.6 \%$ for IMR, $38.8 \%$ for neonatal mortality rate and $51.5 \%$ for post-neonatal mortality rate in 2013 versus 1990.

Conclusion. A significant reduction in infant mortality and its components has been shown, but not enough to meet the Millennium Development Goals. The reduction in IMR gaps reached the set goal; however, inequalities still persist.

Key words: infant mortality rate, Millennium Development Goals, health care disparities, inequality.
\end{abstract}

http:/ /dx.doi.org/10.5546/aap.2016.eng.216

c. National Department of Mother and Child Health. Ministry of Health of Argentina.

E-mail address:

Juliana Z.

Finkelstein, M.D.:

julianazoefinkelstein@

hotmail.com

Funding: None.

Conflict of interest: None.

Received: 08-31-2015

Accepted: 12-17-2015 service determinants prevail (antenatal, childbirth and neonatal care), while among older infants (between 28 and 365 days old), health environmental and socioeconomic factors play a more important role in a child's growth and development. ${ }^{4}$

All births and deaths occurring in Argentina are recorded on a legally binding certificate and included in a statistical report. Live birth statistical reports (LBSRs) and death statistical reports (DSRs) are consolidated at a national and jurisdictional level. Every year, the Health Statistics and Information Department (Dirección de Estadística e Información en Salud, DEIS) of the Ministry of Health (MoH) of Argentina publishes a report called Vital Statistics - Basic information, based on the corresponding statistical reports. $^{5}$

In 2000, Argentina committed, before the United Nations Organization (UN), to meet the Millennium Development Goals (MDGs) by 2015. Among the nine MDGs that have been set forth, MDG 4 (Reduce child mortality) proposes to reduce by two thirds, between 1990 and 2015, the under-five mortality rate and to reduce by $10 \%$ inter-provincial inequalities. ${ }^{6}$

The objective of this article is to describe trends in infant mortality rate in Argentina and inter-jurisdictional gaps, infant mortality magnitude and causes, in compliance with the MDGs.

\section{POPULATION AND METHODS}

A descriptive study on infant mortality in Argentina was conducted based on vital statistics annual reports. Data were analyzed for 1990 (baseline for MDGs) and for the period between 
2000 (year when commitment to the MDGs was signed) and 2013 (the latest year with published data), based on the achievement of MDGs by 2015: an $8.5 \%$ o IMR, a 5.2\%o neonatal mortality rate (NMR) and a 3.2\% post-neonatal mortality rate (PNMR). ${ }^{7}$

Analysis included data on all live births and all deaths of infants younger than one year old (subdivided into the two IMR components: neonatal deaths and post-neonatal deaths), occurred in Argentina and recorded by jurisdiction of maternal place of residence.

For the analysis of infant mortality and its components, instead of absolute numbers, rates were used to make comparisons with other populations and over time.

Infant mortality comprises deaths among infants younger than one year old. IMR was related to infant deaths occurred over one year and to the number of recorded live births over that same year in a given place and expressed per 1000 live births. ${ }^{8}$

Infant mortality included neonatal mortality (deaths occurring between birth and 27 days of life) and post-neonatal mortality (deaths occurring between 28 and 365 days of life).

NMR and PNMR were estimated by relating deaths in each age group to live births, and were expressed per 1000 live births.

The unit of analysis was the country and its jurisdictions. Health outcome measures used to analyze the magnitude and structure of causes of infant mortality and its components included IMR and the following components: NMR and PNMR (continuous quantitative outcome measures) and proportional mortality by cause (continuous quantitative outcome measure).

For the analysis of inequalities among jurisdictions, trends in the inter-provincial Gini coefficient (continuous quantitative outcome measure) for infant mortality developed by the DEIS were studied. The Gini coefficient provides a summary metric used to measure the level of inequality in terms of risk of death distribution in the first year of life. Possible results may have been stated as a value between 0 (perfect equality) and 1 (absolute inequality). ${ }^{9}$

Another resource used to analyze inequalities was the population attributable risk (PAR) percent, which helped to estimate the proportion of mortality rate studied that would have been reduced if the mortality rate in all jurisdictions had been the same as in the province with the lowest rate (continuous quantitative outcome measure).$^{10}$ The PAR for IMR was compared to each IMR component between 1990 and 2013.

Regarding ethical considerations, it should be noted that data used in this study were obtained from a secondary source (Vital Statistics - Basic information). Data processing by the DEIS

FIGURE 1: Trends in infant, neonatal and post-neonatal mortality rates in Argentina, 1990-2013, and reduction targets by 2015 in compliance with the Millennium Development Goals

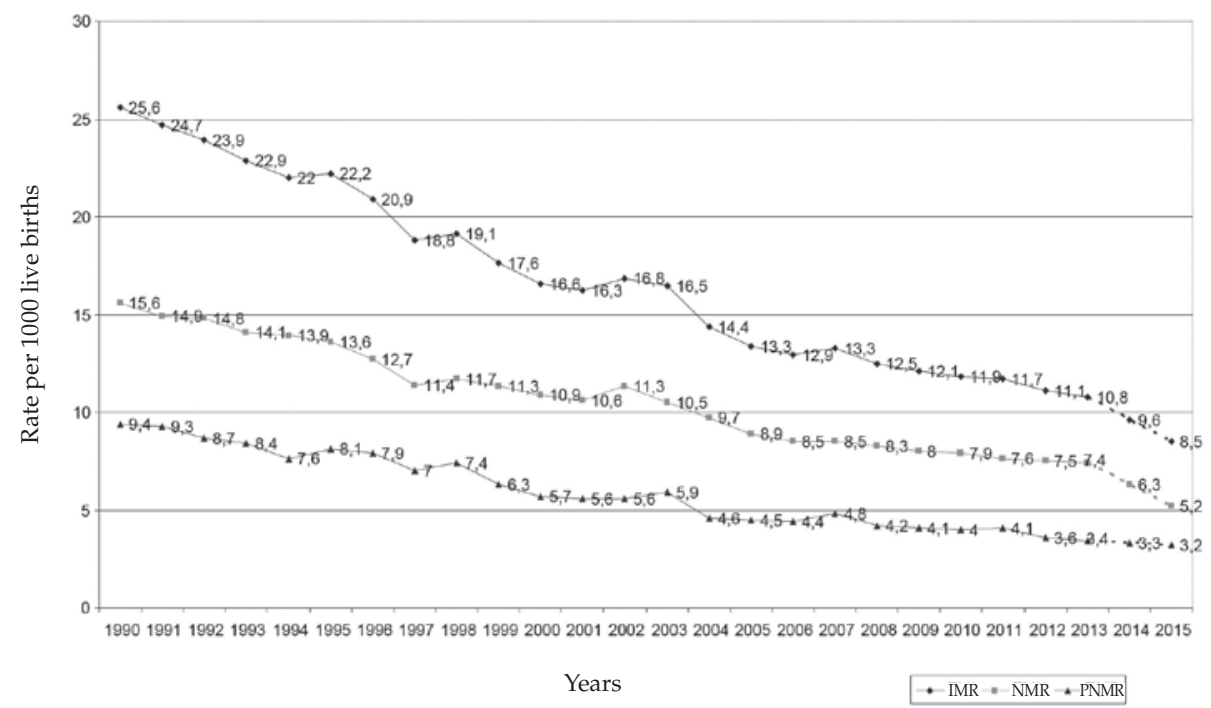

Source: DEIS. MoH. Year 2013.

IMR: infant mortality rate; NMR: neonatal mortality rate; PNMR: post-neonatal mortality rate. 
protects statistical secrecy, so no consent was required for this study.

\section{RESULTS}

In 1990, in Argentina, 678644 live births and 17348 under-one deaths were recorded (10 606 younger than 27 days old and 6364 between 28 and 365 days old. The difference between infant mortality and neonatal and post-neonatal mortality combined corresponded to other infant deaths without age details). IMR was $25.6 \%$, NMR was $15.6 \%$ and PNMR was 9.4\%o. ${ }^{11}$ NMR accounted for $60.9 \%$ of IMR.

In 2013, in Argentina, 754603 live births and 8174 under-one deaths were recorded (5572 younger than 27 days old and 2602 between 28 and 365 days old). IMR was $10.8 \%$, NMR was $7.4 \%$ and PNMR was 3.4\% . NMR accounted for $68.5 \%$ of $\operatorname{IMR}^{12}$ (Figure 1 ).

Between 1990 and 2013, the following reductions were confirmed: $57.8 \%$ in IMR, $52.6 \%$ in NMR, and $63.8 \%$ in PNMR.

\section{Infant mortality by cause}

Infant mortality structure by cause of death in Argentina showed a similar distribution across the years included in the analysis (Table 1).

The leading cause of death in 1990 and in the 2000-2013 period were perinatal conditions (prematurity, conditions typical of the perinatal period, such as omphalitis, neonatal sepsis or hyaline membrane disease), whose relative significance ranged between $49 \%$ and $52.4 \%$. The second leading cause of death were congenital malformations, whose relative significance in infant mortality has increased (from $18.1 \%$ in 1990 to $26.1 \%$ in 2013). ${ }^{11,12}$

Similar values were observed in proportional mortality caused by respiratory diseases in the analyzed period, which peaked in 2003, 2007 and 2011.

In addition, a slow but steady reduction was observed in the relative significance of infectious diseases, which was interrupted in 2011 and then reduced once again (Table 1 ).

\section{Neonatal mortality by cause}

In the studied years, a similar structure was observed in relation to neonatal mortality causes: perinatal conditions and congenital malformations accounted for more than $95 \%$ of neonatal deaths. Although perinatal conditions predominated over the entire period, their relative significance decreased, while that of deaths caused by congenital malformations increased. In 1990, perinatal conditions accounted for $77.3 \%$ of neonatal deaths, while congenital malformations corresponded to $15.8 \%$. In 2013, perinatal conditions accounted for $69.9 \%$ of neonatal deaths, while congenital malformations corresponded to $25.9 \%^{11,12}$ (Table 2).

\section{Post-neonatal mortality by cause}

The structure of post-neonatal mortality

TABLE 1: Trends in infant mortality by leading causes expressed in absolute numbers and as proportional mortality. Total for the country. Argentina. Years 1990 and 2000-2013

\begin{tabular}{|c|c|c|c|c|c|c|c|c|c|c|c|c|c|}
\hline \multirow[t]{2}{*}{ Year } & \multirow[t]{2}{*}{ Total } & \multicolumn{2}{|c|}{$\begin{array}{l}\text { Perinatal } \\
\text { conditions }\end{array}$} & \multicolumn{2}{|c|}{$\begin{array}{c}\text { Congenital } \\
\text { malformations }\end{array}$} & \multicolumn{2}{|c|}{$\begin{array}{l}\text { Respiratory } \\
\text { diseases }\end{array}$} & \multicolumn{2}{|c|}{$\begin{array}{l}\text { Infectious } \\
\text { and parasitic } \\
\text { diseases }\end{array}$} & \multicolumn{2}{|c|}{$\begin{array}{l}\text { External } \\
\text { causes }\end{array}$} & \multicolumn{2}{|c|}{$\begin{array}{l}\text { Other } \\
\text { causes }\end{array}$} \\
\hline & & $\mathrm{N}$ & $\%$ & $\mathrm{~N}$ & $\%$ & $\mathrm{~N}$ & $\%$ & $\mathrm{~N}$ & $\%$ & $\mathrm{~N}$ & $\%$ & $\mathrm{~N}$ & $\%$ \\
\hline 1990 & 17348 & 8600 & 49.6 & 3148 & 18.1 & 1464 & 8.4 & 1219 & 7 & 776 & 4.5 & 2141 & 12.3 \\
\hline 2000 & 11649 & 5955 & 51.1 & 2471 & 21.2 & 823 & 7.1 & 489 & 4.2 & 566 & 4.9 & 1345 & 11.5 \\
\hline 2001 & 11111 & 5588 & 50.3 & 2462 & 22.2 & 825 & 7.4 & 523 & 4.7 & 500 & 4.5 & 1213 & 10.9 \\
\hline 2002 & 11703 & 6101 & 52.1 & 2479 & 21.2 & 825 & 7 & 539 & 4.6 & 430 & 3.7 & 1329 & 11.4 \\
\hline 2003 & 11494 & 5775 & 50.2 & 2423 & 21.1 & 1107 & 9.6 & 518 & 4.5 & 389 & 3.4 & 1282 & 11.2 \\
\hline 2004 & 10576 & 5538 & 52.4 & 2410 & 22.8 & 770 & 7.3 & 384 & 3.6 & 352 & 3.3 & 1122 & 10.6 \\
\hline 2005 & 9507 & 4924 & 51.8 & 2206 & 23.2 & 673 & 7.1 & 330 & 3.5 & 335 & 3.5 & 1039 & 10.9 \\
\hline 2006 & 8986 & 4402 & 49 & 2253 & 25.1 & 727 & 8.1 & 362 & 4 & 293 & 3.3 & 949 & 10.6 \\
\hline 2007 & 9300 & 4557 & 49 & 2096 & 22.5 & 875 & 9.4 & 413 & 4.4 & 318 & 3.4 & 1041 & 11.2 \\
\hline 2008 & 9341 & 4724 & 50.6 & 2285 & 24.5 & 741 & 7.9 & 363 & 3.9 & 220 & 2.4 & 1008 & 10.8 \\
\hline 2009 & 9026 & 4446 & 49.3 & 2257 & 25 & 726 & 8 & 346 & 3.8 & 262 & 2.9 & 989 & 11 \\
\hline 2010 & 8961 & 4487 & 50.1 & 2275 & 25.4 & 675 & 7.5 & 305 & 3.4 & 260 & 2.9 & 959 & 10.7 \\
\hline 2011 & 8878 & 4329 & 48.8 & 2220 & 25 & 764 & 8.6 & 528 & 5.9 & 262 & 3 & 775 & 8.7 \\
\hline 2012 & 8227 & 4068 & 49.4 & 2175 & 26.4 & 609 & 7.4 & 288 & 3.5 & 247 & 3 & 840 & 10.2 \\
\hline 2013 & 8174 & 4160 & 50.9 & 2134 & 26.1 & 565 & 6.9 & 287 & 3.5 & 230 & 2.8 & 798 & 9,8 \\
\hline
\end{tabular}

Source: DEIS. MoH. Year 2013. 
by cause of death was similar across the years included in the analysis ${ }^{11,12}$ (Table 3).

Congenital malformations were the leading cause of post-neonatal deaths, ranging from $20 \%$ to $26.6 \%$, followed by respiratory diseases, ranging from $19.8 \%$ to $25.5 \%$, except in 2002,2003 and 2007, when respiratory diseases became the leading cause of death.

The greatest relative significance $(16.2 \%)$ of infectious diseases as a cause of death was observed in 1990, while in the 2000-2013 period they ranged between $8.4 \%$ and $11.5 \%$.
Proportional mortality caused by perinatal conditions and external causes behaved similarly in the analyzed period (Table 3).

\section{Inter-jurisdictional gaps in infant mortality and its components}

Between 1990 and 2013, the inter-provincial Gini coefficient for IMR decreased by $27 \%$ (Table 4).

The PAR for IMR also decreased by $16.6 \%$ in the studied years. While the PAR was $34.4 \%$ in 1990, it decreased to $28.7 \%$ in 2013.

TABLE 2: Trends in neonatal mortality by leading causes expressed in absolute numbers and as proportional mortality. Total for the country. Argentina. Years 1990 and 2000-2013

\begin{tabular}{|c|c|c|c|c|c|c|c|}
\hline \multirow[t]{2}{*}{ Years } & \multirow[t]{2}{*}{ Total } & \multicolumn{2}{|c|}{ Perinatal conditions } & \multicolumn{2}{|c|}{ Congenital malformations } & \multicolumn{2}{|c|}{ Other causes } \\
\hline & & $\mathrm{N}$ & $\%$ & $\mathrm{~N}$ & $\%$ & $\mathrm{~N}$ & $\%$ \\
\hline 1990 & 10606 & 8201 & 77.3 & 1679 & 15.8 & 726 & 6.8 \\
\hline 2000 & 7650 & 5603 & 73.2 & 1645 & 21.5 & 402 & 5.3 \\
\hline 2001 & 7264 & 5293 & 72.9 & 1615 & 22.2 & 356 & 4.9 \\
\hline 2002 & 7829 & 5772 & 73.7 & 1708 & 21.8 & 349 & 4.5 \\
\hline 2003 & 7345 & 5423 & 73.8 & 1599 & 21.8 & 323 & 4.4 \\
\hline 2004 & 7172 & 5212 & 72.7 & 1656 & 23.1 & 304 & 4.2 \\
\hline 2005 & 6307 & 4598 & 72.9 & 1460 & 23.1 & 249 & 3.9 \\
\hline 2006 & 5903 & 4136 & 70.1 & 1497 & 25.4 & 270 & 4.6 \\
\hline 2007 & 5964 & 4270 & 71.6 & 1428 & 23.9 & 266 & 4.5 \\
\hline 2008 & 6196 & 4429 & 71.5 & 1531 & 24.7 & 236 & 3.8 \\
\hline 2009 & 5956 & 4141 & 69.5 & 1532 & 25.7 & 283 & 4.8 \\
\hline 2010 & 5942 & 4130 & 69.5 & 1553 & 26.1 & 259 & 4.4 \\
\hline 2011 & 5751 & 3957 & 68.8 & 1507 & 26.2 & 287 & 5 \\
\hline 2012 & 5541 & 3807 & 68.7 & 1507 & 27.2 & 227 & 4.1 \\
\hline 2013 & 5572 & 3897 & 69.9 & 1441 & 25.9 & 234 & 4.2 \\
\hline
\end{tabular}

Source: DEIS. MoH. Year 2013.

TABLE 3: Trends in post-neonatal mortality by leading causes expressed in absolute numbers and as proportional mortality. Total for the country. Argentina. Years 1990 and 2000-2013

\begin{tabular}{|c|c|c|c|c|c|c|c|c|c|c|c|c|c|}
\hline \multirow[t]{2}{*}{ Years } & \multirow[t]{2}{*}{ Total } & \multicolumn{2}{|c|}{$\begin{array}{c}\text { Congenital } \\
\text { malformations }\end{array}$} & \multicolumn{2}{|c|}{$\begin{array}{l}\text { Respiratory } \\
\text { diseases }\end{array}$} & \multicolumn{2}{|c|}{$\begin{array}{c}\text { Infectious and parasitic } \\
\text { diseases }\end{array}$} & \multicolumn{2}{|c|}{$\begin{array}{c}\text { Perinatal } \\
\text { conditions }\end{array}$} & \multicolumn{2}{|c|}{$\begin{array}{c}\text { External } \\
\text { causes }\end{array}$} & \multicolumn{2}{|c|}{$\begin{array}{l}\text { Other } \\
\text { causes }\end{array}$} \\
\hline & & $\mathrm{N}$ & $\%$ & $\mathrm{~N}$ & $\%$ & $\mathrm{~N}$ & $\%$ & $\mathrm{~N}$ & $\%$ & $\mathrm{~N}$ & $\%$ & $\mathrm{~N}$ & $\%$ \\
\hline 1990 & 6364 & 1431 & 22.5 & 1264 & 19.9 & 1031 & 16.2 & 268 & 4.2 & 616 & 9.7 & 1754 & 27.6 \\
\hline 2000 & 3999 & 821 & 20.5 & 791 & 19.8 & 391 & 9.8 & 341 & 8.5 & 467 & 11.7 & 1188 & 29.7 \\
\hline 2001 & 3847 & 847 & 22 & 782 & 20.3 & 444 & 11.5 & 293 & 7.6 & 417 & 10.8 & 1064 & 27.7 \\
\hline 2002 & 3874 & 771 & 19.9 & 778 & 20.1 & 423 & 10.9 & 329 & 8.5 & 366 & 9.4 & 1207 & 31.2 \\
\hline 2003 & 4149 & 824 & 19.9 & 1057 & 25.5 & 462 & 11.1 & 352 & 8.5 & 338 & 8.1 & 1116 & 26.9 \\
\hline 2004 & 3402 & 754 & 22.2 & 743 & 21.8 & 335 & 9.8 & 325 & 9.6 & 279 & 8.2 & 966 & 28.4 \\
\hline 2005 & 3200 & 746 & 23.3 & 650 & 20.3 & 283 & 8.8 & 326 & 10.2 & 289 & 9 & 906 & 28.3 \\
\hline 2006 & 3083 & 756 & 24.5 & 685 & 22.2 & 324 & 10.5 & 266 & 8.6 & 242 & 7.8 & 810 & 26.3 \\
\hline 2007 & 3336 & 668 & 20 & 830 & 24.9 & 358 & 10.7 & 287 & 8.6 & 271 & 8.1 & 922 & 27.6 \\
\hline 2008 & 3145 & 754 & 24 & 708 & 22.5 & 318 & 10.1 & 295 & 9.4 & 183 & 5.8 & 887 & 28.2 \\
\hline 2009 & 3070 & 725 & 23.6 & 689 & 22.4 & 291 & 9.5 & 305 & 9.9 & 226 & 7.4 & 834 & 27.2 \\
\hline 2010 & 3019 & 722 & 23.9 & 639 & 21.2 & 253 & 8.4 & 357 & 11.8 & 224 & 7.4 & 824 & 27.3 \\
\hline 2011 & 3127 & 713 & 22.8 & 711 & 22.7 & 321 & 10.3 & 372 & 11.9 & 220 & 7 & 790 & 25.3 \\
\hline 2012 & 2686 & 668 & 24.9 & 582 & 21.7 & 238 & 8.9 & 259 & 9.6 & 207 & 7.7 & 732 & 27.3 \\
\hline 2013 & 2602 & 693 & 26.6 & 535 & 20.6 & 235 & 9 & 263 & 10.1 & 184 & 7.1 & 692 & 26.6 \\
\hline
\end{tabular}

Source: DEIS. MoH. Year 2013. 
The PAR for NMR also reduced between 1990 and 2013 , by $38.8 \%$. While it was $39.7 \%$ in 1990 , it decreased to $24.3 \%$ in 2013.

A reduction of $51.5 \%$ was proven in the PAR for PNMR in the studied years. While it was $78.7 \%$ in 1990 , it decreased to $38.2 \%$ in 2013 (Table 5).

\section{DISCUSSION}

In order to compare these results with those of other countries at a regional and worldwide level, it was necessary to use sources from international organizations. However, heterogeneity in the quality of vital statistics among the different countries required using adjustment mechanisms.

The UN Inter-agency Group ${ }^{13}$ publishes its annual estimations of IMR corrected for each country.

According to this group, in Argentina, IMR was $24 \%$ in 1990 and $13 \%$ in 2011 (latest year with published data), which implies a $45.8 \%$ reduction.
In the same period, IMR reduced worldwide by $39.3 \%$ (1990: $61 \%$ versus $2011: 37 \%$ ). The same authors also reported that IMR decreased by $61.9 \%$ in Latin America and the Caribbean as

TABLE 4: Trends in the Gini coefficient for the interprovincial mortality rate. 1990 and 2000-2013

\begin{tabular}{lc}
\hline Year & Gini (IMR) \\
\hline 1990 & 0.100 \\
2000 & 0.124 \\
2001 & 0.122 \\
2002 & 0.130 \\
2003 & 0.118 \\
2004 & 0.117 \\
2005 & 0.104 \\
2006 & 0.100 \\
2007 & 0.090 \\
2008 & 0.092 \\
2009 & 0.091 \\
2010 & 0.088 \\
2011 & 0.084 \\
2012 & 0.081 \\
2013 & 0.073 \\
\hline
\end{tabular}

Source: DEIS. MoH. Year 2013.

IMR: infant mortality rate.

TABLE 5: Comparison among infant, neonatal and post-neonatal mortality rates by jurisdiction and population attributable risk percent. Years 1990 and 2013

\begin{tabular}{|c|c|c|c|c|c|c|}
\hline \multirow{2}{*}{ Jurisdiction } & \multicolumn{2}{|c|}{ IMR } & \multicolumn{2}{|c|}{ NMR } & \multicolumn{2}{|c|}{ PNMR } \\
\hline & Year 1990 & Year 2013 & Year 1990 & Year 2013 & Year 1990 & Year 2013 \\
\hline Total for the country & $25.6 \%$ & $10.8 \%$ & $15.6 \%$ & $7.4 \%$ & $9.4 \%$ & $3.4 \%$ \\
\hline CABA & $16.8 \%$ о & $8.9 \%$ & $11.2 \%$ & $6.5 \%$ & $5.5 \%$ & $2.5 \%$ \\
\hline Buenos Aires & $24.2 \%$ & $11 \%$ & $14.9 \%$ & $7.2 \%$ & $8.8 \%$ & $3.7 \%$ \\
\hline Catamarca & $34.6 \%$ & $9.7 \%$ & $19.6 \%$ & $7 \%$ & $13.3 \%$ & $2.7 \%$ \\
\hline Córdoba & $22.2 \%$ & $9.6 \%$ & $14.2 \%$ & $6.5 \%$ & $7.5 \%$ & $3.2 \%$ \\
\hline Corrientes & $31.7 \%$ & $14.9 \%$ & $18.1 \%$ & $11.4 \%$ & $13.3 \%$ & $3.5 \%$ \\
\hline Chaco & $35.8 \%$ & $11.6 \%$ & $21.2 \%$ & $6.5 \%$ & $14.6 \%$ & $5.1 \%$ \\
\hline Chubut & $20.6 \%$ & $9.3 \%$ & $13.1 \%$ & $6.2 \%$ & $7 \%$ & $3.2 \%$ \\
\hline Entre Ríos & $24.3 \%$ о & $9.2 \%$ & $15.9 \%$ & $6.2 \%$ & $8.2 \%$ & $3 \%$ \\
\hline Formosa & $33.2 \%$ & $14.2 \%$ о & $17.3 \%$ & $9.3 \%$ & $15.8 \%$ о & $7.9 \%$ \\
\hline Jujuy & $35.8 \%$ & $11.8 \%$ & $17.2 \%$ & $7.8 \%$ & $16.4 \%$ & $4 \%$ \\
\hline La Pampa & $22.1 \%$ & $9.9 \%$ & $15.7 \%$ о & $7.6 \%$ & $5.4 \%$ & $2.3 \%$ \\
\hline La Rioja & $28.8 \%$ о & $12 \%$ & $19.3 \%$ & $8.6 \%$ & $9.5 \%$ & $3.4 \%$ \\
\hline Mendoza & $21.1 \%$ & $8.5 \%$ & $14.1 \%$ & $6.2 \%$ & $6.9 \%$ & $2.3 \%$ \\
\hline Misiones & $31.8 \%$ & $10.4 \%$ & $19.9 \%$ & $6.6 \%$ & $12 \%$ & $3.8 \%$ \\
\hline Neuquén & $16.9 \%$ & $10.3 \%$ & $9.4 \%$ & $6.6 \%$ & $7.6 \%$ & $3.7 \%$ \\
\hline Río Negro & $23.1 \%$ & $11.4 \%$ & $13.6 \%$ & $8.2 \%$ & $8.7 \%$ & $3.3 \%$ \\
\hline Salta & $32.3 \%$ & $14.1 \%$ & $16.7 \%$ & $9.7 \%$ & $15.5 \%$ & $4.5 \%$ \\
\hline San Juan & $24.4 \%$ о & $12.3 \%$ & $15 \%$ & $8.1 \%$ & $9.3 \%$ & $4.2 \%$ \\
\hline San Luis & $29.7 \%$ & $8.6 \%$ & $18.6 \%$ & $6 \%$ & $10.9 \%$ & $2.6 \%$ \\
\hline Santa Cruz & $20.7 \%$ & $9.5 \%$ & $14.4 \%$ & $6.7 \%$ & $6.3 \%$ & $2.8 \%$ \\
\hline Santa Fe & $28.3 \%$ & $9.8 \%$ & $19.1 \%$ & $7.2 \%$ & $8.9 \%$ & $2.6 \%$ \\
\hline Santiago del Estero & $28.3 \%$ о & $11.5 \%$ & $14.6 \%$ & $7.9 \%$ & $10.8 \%$ & $3.6 \%$ \\
\hline Tucumán & $28.5 \%$ & $13.1 \%$ & $16.8 \%$ & $10.2 \%$ & $9.5 \%$ & $2.9 \%$ \\
\hline Tierra del Fuego & $27.9 \%$ & $7.7 \%$ & $25.9 \%$ & $5.6 \%$ & $2 \%$ & $2.1 \%$ \\
\hline$P A R$ & $34.4 \%$ & $28.7 \%$ & $28.2 \%$ & $24.3 \%$ & $78.7 \%$ & $38.2 \%$ \\
\hline
\end{tabular}

Source: DEIS. MoH. Year 2013.CABA: Autonomous City of Buenos Aires; IMR: infant mortality rate;

NMR: neonatal mortality rate; PNMR: post-neonatal mortality rate; PAR: population attributable risk percent. 
a whole, 55\% in Europe and Central Asia, 51.9\% in the Middle East and North Africa, 35.5\% in sub-Saharan Africa, $59.55 \%$ in East Asia and the Pacific, and $43.5 \%$ in South Asia. ${ }^{14}$

That is to say, according to the UN Interagency Group, the IMR reduction achieved by Argentina was greater than that observed at a worldwide level and at some regional levels; however, the percentage of reduction was lower than that achieved in other regions, including Latin America.

In the studied period, while NMR in Argentina accounted for $60.9 \%$ of IMR in 1990 and increased to $68.5 \%$ in 2013 , at a global level NMR accounted for $53.6 \%$ of IMR in 1990 and increased to $58.2 \%$ in 2013.

The analysis of the infant mortality structure by cause in Argentina showed that, since 1990, the leading cause of infant deaths were perinatal conditions, followed by congenital malformations. At a global level, between 1990 and 2010 (the latest year with published data on mortality disaggregated by cause), the structure of infant mortality causes has changed mainly due to a reduction in infectious diseases, which were the leading cause of death in 1990 and were replaced by perinatal conditions in 2010, therefore remaining in the second place. Since 1990, congenital malformations have been the third cause of death. . $^{15,16}$

In relation to neonatal mortality worldwide, over the entire studied period, the leading cause of death were perinatal conditions, similarly to what has been observed in Argentina. With a lower rate, infectious diseases were the second cause (in Argentina, they account for a marginal percent), followed by congenital malformations (the second cause of neonatal mortality in Argentina). ${ }^{15,16}$

Post-neonatal mortality worldwide was primarily caused, in the studied years, by infectious diseases (62.8\% in 1990 and $48.6 \%$ in 2010). These were followed by tropical diseases and malaria, nutritional deficiencies, perinatal conditions, congenital anomalies and external causes $(5-10 \%$ each cause, for each year). The structure of postneonatal mortality causes was especially different in Argentina, where the leading cause was congenital malformations, followed by respiratory diseases, perinatal conditions, infectious and parasitic diseases, and external causes. ${ }^{15,16}$

The lower relative significance of infectious and parasitic diseases, respiratory diseases and malnutrition in Argentina, compared to the structure of infant mortality worldwide, evidences that the level of development in Argentina has been higher. ${ }^{17}$

It is worth noting that the structure of infant mortality causes worldwide is strongly determined by the structure of infant death causes in Asia and Africa, which account for more than $90 \%$ of underone deaths at a global level. ${ }^{14}$

However, the fact that neighboring countries with a similar development level as Argentina have achieved a higher reduction in their risk of infant mortality underscores the need to deepen strategies aimed at ensuring population access to health care services and the quality of such services.

Knowing the structure of causes of infant mortality and of each of its components is critical for the strategic planning of public policies to improve mother and child health care.

The analysis of neonatal mortality causes demonstrated the need to deepen strategies aimed at improving a timely and adequate access to health care during pregnancy and childbirth, and an optimal newborn care.

The causes of post-neonatal mortality pointed out the need to continue providing health care beyond the neonatal period, especially to patients at a biological or socio-environmental risk.

This study has some weaknesses, such as having analyzed data published by the DEIS, obtained from the Vital Statistics System and based on LBSRs and DSRs, and the fact that event under-recording (birth or death) or an incorrect identification of the cause of death in DSRs may affect analysis results.

Notwithstanding this, and taking into account the strengths of the study, it is worth noting that more than $99.5 \%$ of births in Argentina take place in health facilities and that a mandatory requirement for burial implies the concurrent recording of death certificates and DSRs, therefore reducing any potential under-recording of these events.

\section{CONCLUSION}

Between 1990 and 2013, in Argentina, reductions in infant mortality and each of its components were confirmed (57.8\% in IMR, 52.6\% in NMR and $63.8 \%$ in PNMR).

In 2013, a $10.8 \%$ IMR, a $7.4 \%$ NMR, and a $3.4 \%$ PNMR were recorded, but these values do not seem to be enough to reach the MDG target, which aim at an $8.5 \%$ IMR, a 5.2\% NMR, and a 3.2\%o PNMR by 2015.

Inequalities in IMR and its components have 
decreased over the years included in the analysis in Argentina. The inter-provincial Gini coefficient for IMR decreased by $27 \%$ in 2013 compared to 1990, which is higher than the MDG target set at a $10 \%$ reduction. However, in Argentina inequalities still exist as far as the risk of death in the first year of life.

\section{REFERENCES}

1. Naciones Unidas. Objetivos de Desarrollo del Milenio. Informe de 2014. Nueva York, 2014. [Accessed on: August 6, 2014]. Available at: http://www.undp.org/content/ dam/undp/library/MDG/spanish/UNDP_MDGReport_ SP_2014Final1.pdf.

2. United Nations Children's Fund, World Health Organization, World Bank, United Nations-Population Division. Levels and trends in child mortality. Report 2014. Nueva York, 2014. [Accessed on: April 4, 2015]. Available at:http://www.unicef.org/spanish/media/files/Levels_ and_Trends_in_Child_Mortality_2014(1).pdf.

3. Organización Mundial de la Salud. Reducción de la mortalidad en la niñez. Nota descriptiva N. ${ }^{\circ} 178$. Ginebra, 2014. [Accessed on:September 1,2014]. Availableat: http:// www.who.int/mediacentre/factsheets/fs178/es/.

4. Argentina. Ministerio de Salud de la Nación. Dirección Nacional de Maternidad e Infancia. Análisis de la Mortalidad Materno Infantil. República Argentina, 20032012. Buenos Aires, 2014. [Accessed on: March 1, 2015]. Available at: http:/ /www.msal.gov.ar/images/stories / bes/ graficos/0000000616cnt-analisis_mortalidad_ materno_infantil_argentina-2003-2012.pdf.

5. Argentina. Ministerio de Salud de la Nación. Dirección de Estadísticas e Información en Salud. Sistema Estadístico de Salud y Sistemas de Vigilancia Epidemiológica. Objetivos y Funcionamiento. Buenos Aires, 2015. [Accessed on: April 10, 2015]. Available at: http://www.deis.msal.gov.ar/ quienes_funcion.htm.

6. Brisson ME, García Conde S, Di Pietro L. Objetivos de Desarrollo del Milenio. La Cumbre del Milenio y los compromisos internacionales. Buenos Aires: Consejo Nacional de Coordinación de Políticas Sociales; 2014. [Accessed on: November 1, 2015]. Available at: http://www.politicassociales.gov. ar/ odm/ODM_SerieDocumentoTrabajo / ODM_ SerieDocumentoTrabajoN1.pdf.

7. Argentina. Presidencia de la Nación. Consejo Nacional de Coordinación de Políticas Sociales. Objetivos de Desarrollo del Milenio. Informe País Argentina 2012. Buenos Aires, 2012. [Accessed on: April 10, 2015]. Available at: http:// www.politicassociales.gov.ar/odm/pdf/IP2012.pdf.

8. Argentina. Ministerio de Salud de la Nación. Dirección de Estadísticas e Información en Salud. Definiciones y conceptos en estadísticas de salud. Buenos Aires, 2015. [Accessed on: October 21,2015]. Available at: http://www. deis.msal.gov.ar/definiciones.htm\#5.

9. Argentina. Ministerio de Salud de la Nación. Indicadores básicos Argentina 2014. Buenos Aires, 2014. [Accessed on: November 10, 2015]. Available at: http: / / www.deis.msal. gov.ar/publicaciones/archivos/indicadores_2014.pdf.

10. Schneider MC, Castillo-Salgado C, Bacallao J, Loyola E, et al. Métodos de medición de las desigualdades de salud. Rev Panam Salud Pública 2002;12(6):398-415.

11. Argentina. Ministerio de Salud y Acción Social dela Nación. Secretaría de Salud. Estadísticas de salud. Estadísticas vitales. Información básica. Año 1990. Serie 5. Número 34. Buenos Aires, 1992.

12. Argentina. Ministerio de Salud de la Nación. Dirección de Estadísticas e Información de Salud. Estadísticas Vitales. Información básica. Año 2013. Buenos Aires, 2014. [Accessed on: April 10, 2015]. Available at: http://www. deis.msal.gov.ar/Publicaciones/Archivos/Serie5Nro57. pdf.

13. United Nations Children's Fund, World Health Organization, World Bank, United Nations-Population Division. Levels and trends in child mortality. Report 2012. Page 15. New York, 2012. [Accessed on: May 7, 2015]. Available at: http:/ / www.unicef.org/videoaudio/PDFs/ UNICEF_2012_child_mortality_for_web_0904.pdf.

14. United Nations Children's Fund, World Health Organization, World Bank, United Nations-Population Division. Levels and trends in child mortality. Report 2012. Page 27. New York, 2012. [Accessed on: May 7, 2015]. Available at: http://www.unicef.org/videoaudio/PDFs/ UNICEF_2012_child_mortality_for_web_0904.pdf.

15. Wang H, Liddell CA, Coates MM, Mooney MD, et al. Global, regional, and national levels of neonatal, infant, and under-5 mortality during 1990-2013: a systematic analysis for the Global Burden of Disease Study 2013. Lancet 2014;384(9947):957-79.

16. Wang H, Dwyer-Lindgren L, Lofgren KT, Rajaratnam JK, et al. Age-specific and sex-specific mortality in 187 countries, 1970-2010: a systematic analysis for the Global Burden of Disease Study 2010. Lancet 2012;380(9859):2071-94.

17. Omran AR. The epidemiologic transition. A theory of the epidemiology of population change. Milbank Mem Fund $Q$ 1971;49(4):509-38. 